\title{
THE LION-GAZELLE MOSAIC AT KHIRBAT AL-MAFJAR
}

The bath hall at Khirbat al-Mafjar, one of the most remarkable buildings dating from the Umayyad period, is well known to historians of Islamic art through the excavation and reconstruction of its layout by Robert Hamilton. ${ }^{1}$ Hamilton has subsequently added a new dimension to the interpretation of this building by publishing a biography of its probable founder, the caliph Walid II, and translating excerpts of the poetry composed by this fascinating and eccentric caliph. ${ }^{2}$ In his biography Hamilton not only further supports his earlier argument that the palace and bath of Khirbat al-Mafjar should be attributed to Walid ibn Yazid or Walid II (74344 ), but he also gives life and meaning to the various elements of its architecture and decoration. Seen from this enhanced perspective, the bath hall seems to have been an appropriate stage for the extravagant life Walid II led, as described by his biographers, which eventually led to his assassination. ${ }^{3}$

Stimulated by Hamilton's interpretation of the bath complex, I was attracted particularly by the famous mosaic panel representing a lion attacking a gazelle underneath a tree. This panel is on the floor of the room,

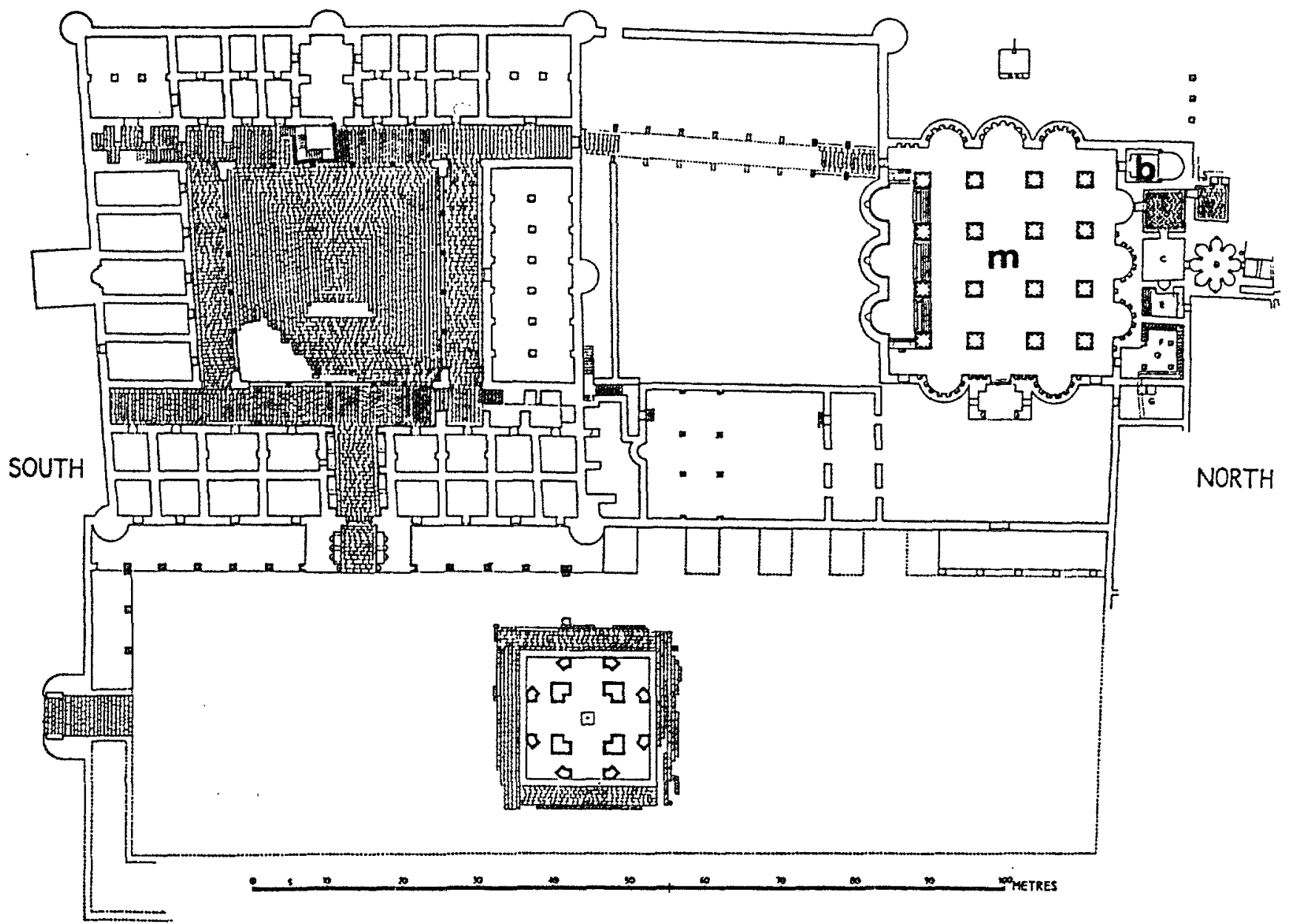

Fig. 1. The general plan of Khirbat al-Mafjar. b: the bahw, m: the "music room". (after Hamilton) 
which, following Walid's biographical sources, Hamilton calls a bahw, meaning reception hall, and which he identifies as a private room (fig. 1).

Walid II, the patron of Khirbat al-Mafjar, and the son of the caliph Yazid, is described in the sources as what one might today call a playboy ( $\mathrm{khall}^{-\mathrm{C}}$ ). He was also an athlete and huntsman of great talent and an important poet who had a significant impact on the style of Arab poetry in the subsequent period, especially on the work of Abu Nuwas (died ca. 815). ${ }^{4}$ Poetry at that time was often sung, and Walid's dedication to poetry was complemented by his passion and talent for music. He surrounded himself with poets, musicians, and dancers. Inspired by this aspect of his life Hamilton designated the vaulted hall that adjoins the bath proper as the "music room," noting that there was an "unmistakable resonance between the defiant and often humorous eccentricity of Walid and peculiar features discernible in the buildings."

The hall is reached from a projecting porch; sixteen pillars support the vaults of its roof. The porch was richly adorned with stucco floral motifs and representations of athletes, half-naked girls, gazelles, and sheep. A

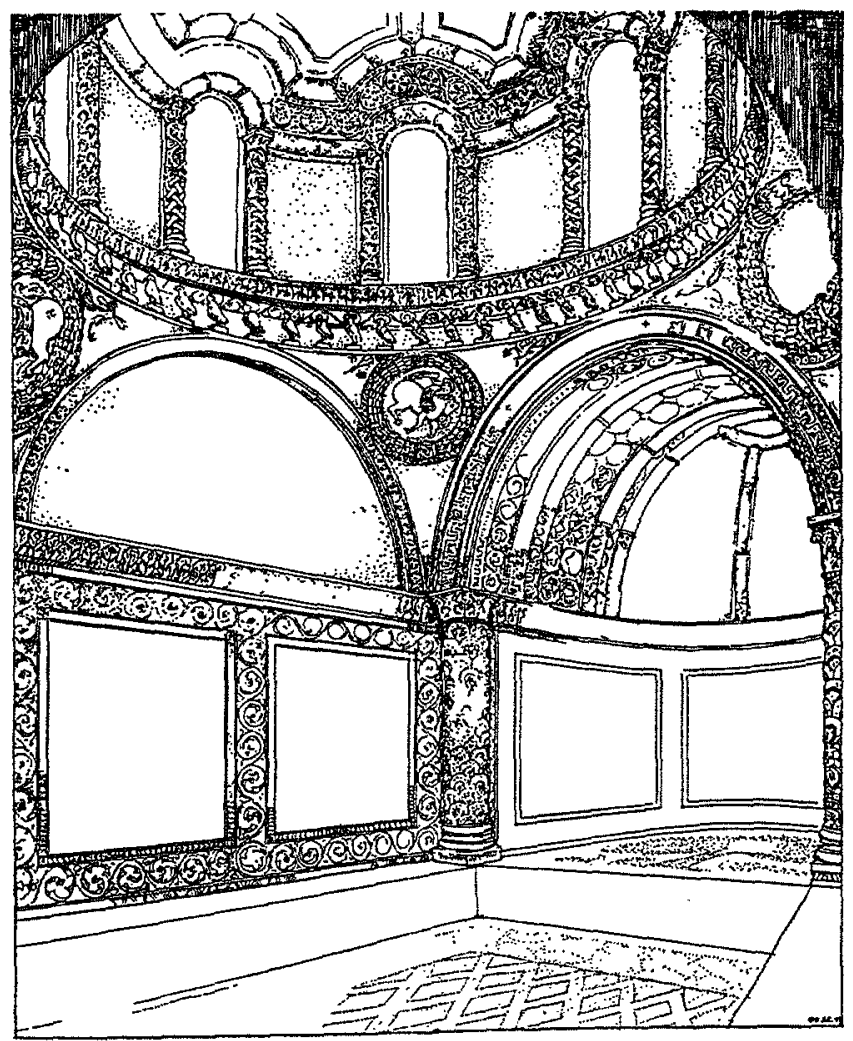

Fig. 2. The $b a h z$, restored perspective. (after Hamilton) central niche was intended for a stucco statue of the caliph (most likely the caliph in spe at the time the bath was erected) standing above a pair of lions. On each of three sides of the hall three apses were once roofed by half-domes. These nine apses and two others flanking the porch entrance, making a total of eleven, complete the layout. The hall's floor was composed of a patchwork of mosaic panels in a large variety of geometric patterns that rarely repeat. The central mosaic "carpet" that was once surmounted by the central dome is correspondingly circular. The complex was never completed; it was destroyed by an earthquake in 746 shortly after it was built. Only the mosaic pavement remains in its original condition.

Appended to the music room on the north were the bath and four rooms; on the south a few steps led down to a long plunge pool.

At the northwestern corner of the music room, adjacent to the structures of the steam bath, is the small absidal room or bahw (fig. 2). Its floor is covered by two mosaic panels - one rectangular with a geometric design, and the other an arched panel filling the slightly elevated floor of an apse. The arched panel has the representation of the lion attacking the gazelle (fig. 3). It is the only mosaic panel in the complex that has a figural motif, suggesting that this motif had a symbolic meaning of particular significance.

At the pictorial center of the mosaic is a large tree bearing fruit that look like apples. The foliage of the tree seems to grow on both sides from two vertical parallel trunks connected by a smaller branch. The viewer looking into the room can see the lion attacking a gazelle on his right side underneath the tree. On the left side two other gazelles are grazing.

Ettinghausen, in his article "The Conquering Lion," saw the mosaic as a symbol of royalty. Later, in his "Throne and Banquet Hall," he added a more political dimension to this interpretation, ${ }^{5}$ identifying the room as a "throne room" and the image itself as a representation of där al-isläm, the Muslim world, symbolized by the two grazing gazelles, in opposition to the dar al-harb, the world outside the realm of Islam, symbolized by the attacking lion, basing this interpretation on an analogy with the Christian iconography of opposing good and evil. Such a political interpretation is, however, not consistent with the mosaic's location in an almost hidden corner of the music room, adjacent to the bath rooms, i.e., in a place that was obviously a very private, even intimate, section of the palace complex. The symbol of Islam and the world seen by Ettinghausen would require 


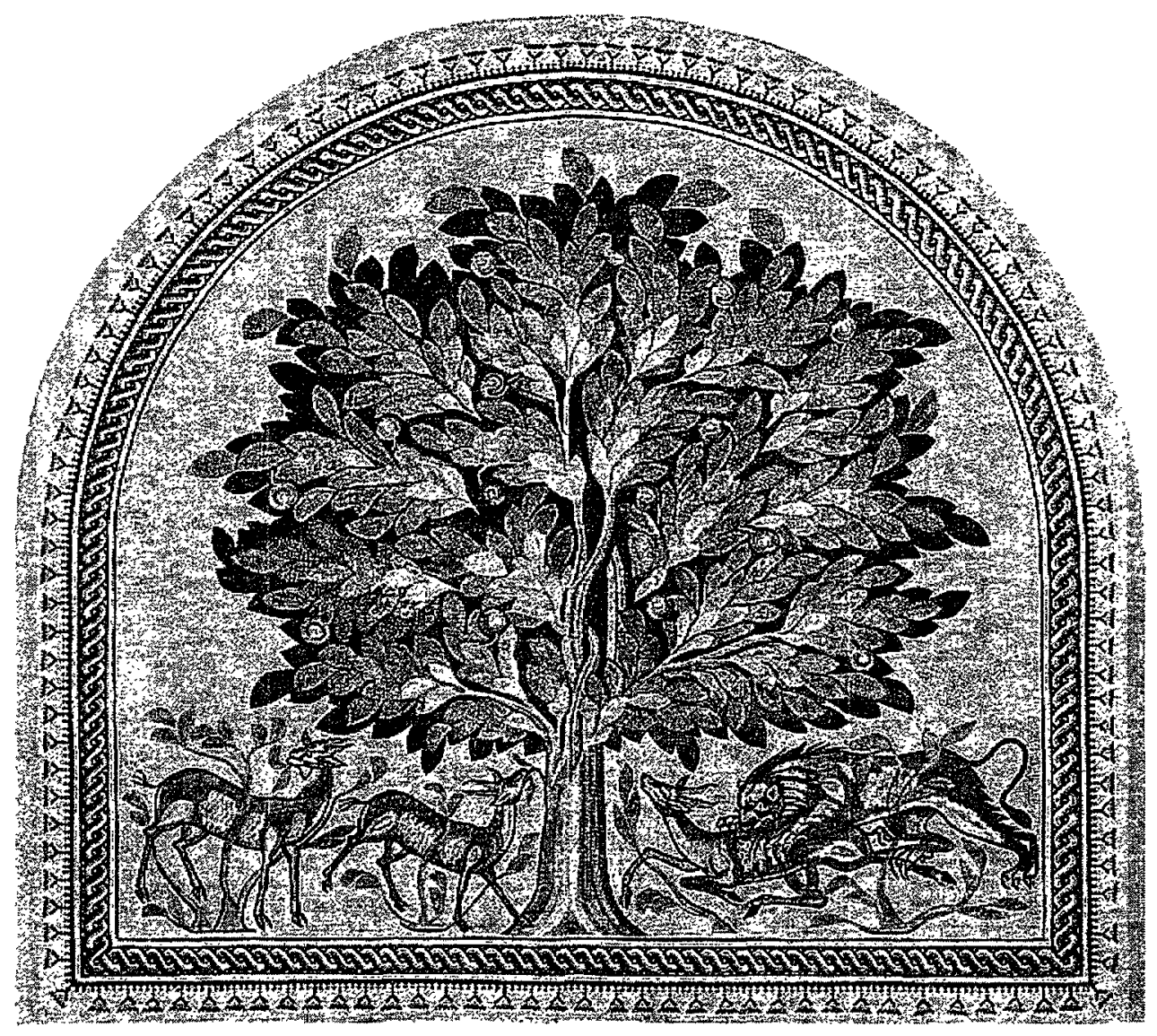

Fig. 3. The lion-gazelle mosaic. (after Hamilton)

a more ceremonial and central setting, indeed a throne room, which this $b a h w$ by no means could have been. Hamilton's interpretation of the bahw as a private room is therefore more plausible, and poses no problem for Ettinghausen's earlier version that the lion motif symbolizes royalty. The panel was designed to express the private character of the room as well as the royal character of its master.

As has been demonstrated by Hartner and Ettinghausen, the theme of the "conquering lion" is a very old one, dating to ancient Mesopotamia and Iran. Throughout the centuries it was given a multitude of meanings that evolved over time and place. In the Iranian world it was an astronomical symbol for the constellations of Leo and Taurus. The triumphant lion (Leo being the domicile of the sun) destroys the bull, thus allowing the sun to reappear and spring to follow winter. According to Hartner and Ettinghausen, the astronomical symbol may later have given way to the more political meaning of power and royalty.
In ancient Mesopotamian and Iranian images, the lion is fighting with a sizable animal, usually a bull but sometimes also a stag or a deer of the lion's size, to make the combat appear to be between two equal powers, an expression of the summer-winter cycle (fig. 4). In classical and in Byzantine art we find this motif slightly modified with a lion attacking a large horse. ${ }^{6}$

Mosaics from the Byzantine period in Syria and Jordan brought to light by recent excavations show that, despite regional variations, hunting scenes, including that of a lion pursuing a stag, were everywhere a favorite motif for mosaic pavements. In addition to the hunting scenes, there are also other types of zoomorphic representations showing wild and tame animals, sideby-side in a peaceful context. ${ }^{7}$ In the Transjordanian socalled Madaba school of mosaics, where geometric patterns occupy an important place, the figural themes display a narrative tendency in the representations of hunting scenes and country life. Both the geometric mosaic carpets of Khirbat al-Mafjar and the wall paint- 


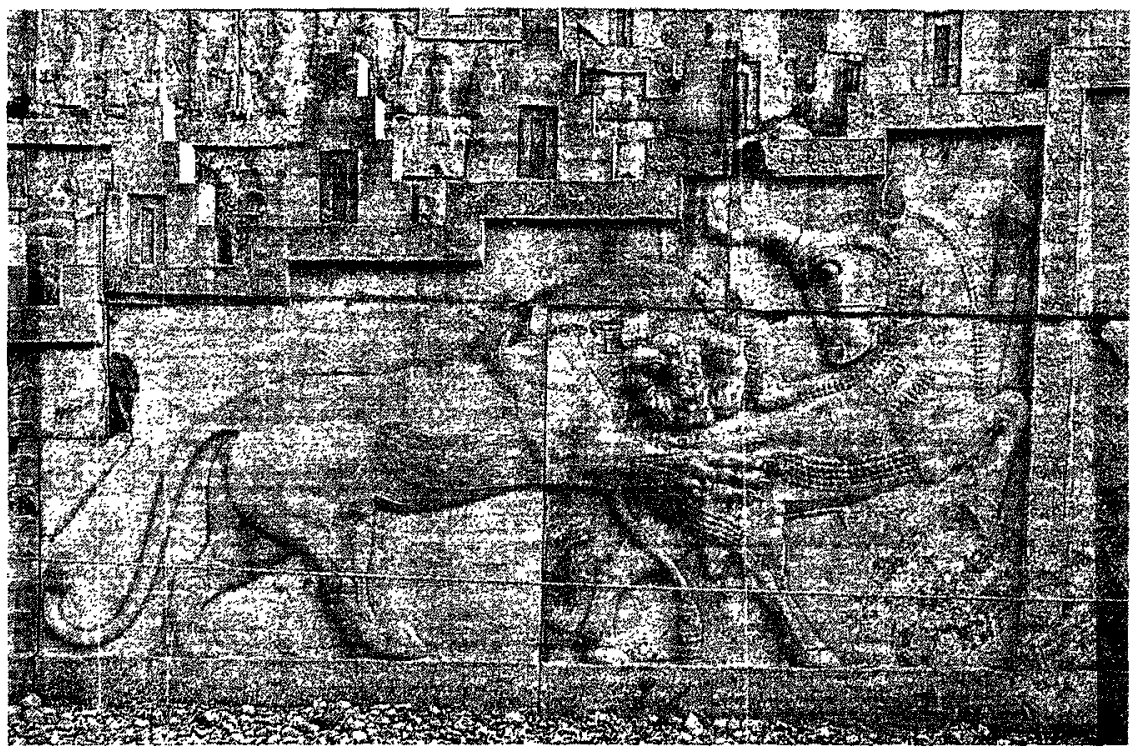

Fig. 4. Relief in Persepolis with lion attacking a bull.

ings of Qusayr Amra seem to have their roots here. ${ }^{8}$

The peaceful cohabitation of a lion and other animals appears both in northern Syria and in Transjordan. A lion faces a bull on a sixth-century Antioch mosaic panel mentioned by Ettinghausen. ${ }^{9}$ As at Khirbat al-Mafjar, a tree with fruit is in the center of the picture. On the right side underneath the tree a bull stands facing a lion advancing from the left. An inscription on the tree indicates that the image represents peace between enemies, an illustration of a Messianic vision of paradise: "The lion and the ox shall eat straw together" (Isaiah 62:25). We find this motif on mosaic pavements at Madaba and in a church at $\mathrm{Ma}^{\mathrm{C}}$ in in Jordan dated $719-20$, i.e., from the Umayyad period, with the same inscription. ${ }^{10}$

At Khirbat al-Mafjar, a significant element seems to suggest that the lion is not as dangerous as he first appears. In all the early representations of the conquering lion, the prey stands alone against the lion, whereas at the bahw the gazelle is accompanied by two others who do not seem at all disturbed by the lion's presence. They make no effort to escape, in contrast to so many hunting scenes in pre-Islamic and Islamic art where the pursued animals run for their lives ahead of the hunter. Here their bodies are directed toward the attacking lion, and their posture and attitude have no suggestion of the lion as threat.

A further argument for the interpretation of the lion motif as non-belligerent is the orientation of the panel, a point that Ettinghausen has already raised. The image, however, is not oriented, as Ettinghausen claimed, to face someone seated in the apse and facing the entrance, but rather to face someone entering the room. To someone looking from within the apse, the tree would appear upside-down; to someone coming into the room, the scene is upright. In this case the lion is on the right-hand side. As Ettinghausen observed, in Christian iconography the right side is auspicious in contrast to the left. ${ }^{11}$ There is unequivocal evidence that the same is also true in Umayyad culture and poetry. Walid himself expressed this idea on more than one occasion. In one poem, he says:

We caught and would have killed an antelope That ran auspicious from the right. ${ }^{12}$

And elsewhere, in Walid's poetry:

Pass the cup round to the right Don't pass it to the left! !. $^{\text {. }}$

By placing the lion on the right-hand side of the viewer, the artist made it clear that the lion was auspicious without, however, implying a negative association with the left side. If we are to look for an antithesis between the two sides of the image, it is not good and evil that we should expect to find in a private room within a bath complex, but rather strength and weakness, or perhaps more particularly, the male symbolized by a "conquer- 
ing lion" and the female symbolized by the graceful gazelles.

Looking at the lion's prey, the gazelle, the most striking feature about its appearance is its delicate and graceful form, the slender body with a long neck and the finely shaped head. If the figure represents gender, this should be female beauty, as opposed to the virile features associated with a bull or a stag. The gazelles are obviously smaller than the lion, making combat between them patently uneven.

Anyone familiar with Arab poetry or Arab poetical forms, old or contemporary, will appreciate that the gazelle in Arabic culture, in both literary and colloquial language, is a symbol of female beauty. Its comparison with the beloved is "one of the major topoi of traditional Arabic love poetry." ${ }^{14}$ Some linguists even relate the word ghazāl (gazelle) with ghazal (love poetry). ${ }^{15}$ The virgins of Paradise, the houris, are by definition girls with large eyes similar to those of the gazelles. ${ }^{16}$

Walid II himself wrote a poem that includes this image:

Salmā my love, an antelope I love

For the dark eyes and spotless neck and throat. ${ }^{17}$

Besides being a symbol of female beauty, the antelope or gazelle was celebrated repeatedly in Arab hunting poetry of the pre-Islamic or Jahiliyya and the Umayyad periods as a beautiful animal of prey whose elegance and swiftness fascinated the hunter and seduced him to pur-. sue it. In the literature dealing with the interpretation of dreams, one finds interesting information in this context. In the section on the interpretation of dreams, acquiring a gazelle by hunting techniques equals becoming the owner of a slave-girl by way of ruse or fraud, or marrying a wife. Killing the gazelle symbolizes deflowering a slave girl. ${ }^{18}$

Walid, as patron of Khirbat al-Mafjar, poet, huntsman, and womanizer, dedicated most of his poetry to wine and love. In one poem about a hunting excursion, Walid pursued an antelope, but stopped short of killing her after he looked at her neck and her eyes which reminded him of his beloved Salma:

\footnotetext{
We caught and would have killed an antelope That ran auspiciously to the right.

But then it gently turned its eyes and looked The very image of your look!

We let it go. Were it not for our love For you, it surely would have died. Now, little antelope, you're free and safe.
}

\author{
So off you go, \\ Happy among the other antelopes. ${ }^{19}$
}

At first glance, Walid looks at an antelope and sees his prey. On the second look, however, he recognizes his beloved Salma and the hunter becomes the lover.

It is tempting to see the mosaic panel of the $b a h w$ as an illustration of this episode: on the right side the hunter pursues his prey; on the left side, the antelope or gazelle returns to her companions. A variation on this motif in other sources mentions that the caliph Abd al-Malik ibn Marawan is said to have let a gazelle escape after he captured her because of her resemblance to his beloved: ${ }^{20}$

O likeness of Laylā, never fear!

For I am your friend, today, $O$ wild deer!

Then I say, after freeing her from her fetters:

You are free for the sake of Laylä, for ever!

The hunter freeing a gazelle is a related topos. Bürgel refers to a poem in Kitäb al-Aghānīin which the husband of the beloved woman turns into a wolf and kills the gazelle, but is himself killed by the vengeful hunter. Another related motif frequently used in the poetry of Bashshar ibn Burd (715-83), shows the reverse situation: the hunter is himself killed by love sickness for the deer. Bürgel relates the image of the murderous glances of the gazelle back to an ancient Arabian tradition that attributes magic qualities to the bovine animal. Thus the gazelle may be attacked by the hunter, but she has her own deadly weapons. ${ }^{21}$ This establishes an equilibrium of power which may explain the serenity of the two gazelles grazing on the left-hand side of our mosaic panel. It may be going too far, perhaps, to see them as awaiting their turn.

\section{A lion chased by a graceful gazelle! Never before did you see a gazelle hunt a lion! ${ }^{22}$}

Two centuries later the poet al-Sanawbari (d. 945) wrote two verses on the women of the city of Raqqa with a similar theme:

\section{We may have hunted her gazelles one day Her gazelles hunted our hearts forever. ${ }^{23}$}

The lion, in Arabic as in other literature, is a symbol of strength, courage, and royalty, an image that has ancient origins..$^{24}$ The statue of Walid once standing in a niche above the porch shows him with a pair of heraldic lions at his feet. It is not difficult to imagine that Walid identi- 
fied himself - or was identified - with a lion. Ironically, in a poem referring to Walid's assassination, the caliph is compared with a lion in whose body the spears are breaking. ${ }^{25}$

It seems, therefore, that the artist of the bahw mosaic modified a current motif and adapted a familiar iconography to conform to the location and purpose of the building for which it was designed. Interpreting the lion mosaic as having an erotic meaning would suit the private character of the bahw and its location within the complex. The function of the room as chambre separée in this hedonistic setting would conform with the orgiastic scenes narrated by Walid's biographers. It does not require much imagination to assume that when he withdrew into this room he was not alone.

If we look closely at the fruit tree in whose shade the action takes place, we can see that its two branches are entangled in a manner that suggests an erotic embrace. Here again, a poem by Walid addressed to his beloved Salma seems to support this interpretation. The comparison of the beloved woman with a garden or a paradise is another theme used in early Arab poetry: ${ }^{26}$

For Salma is my little garden and my bliss. ${ }^{27}$

and elsewhere:

Salma, you were a paradise, and its fruits In all their kinds near ripe for harvesting. ${ }^{28}$

Walid goes on with his description of the beloved garden after Salma died, with the following verse: "Its fruits were scattered by the autumn winds." The word used in the poem for paradise is janna, which means also garden; "fruits near ripe for harvesting" are in fact represented in the tree of our mosaic panel, so that here, too, the idea of paradise is near. The juxtaposition of two images - the gazelle and the garden - is absolutely consistent with the Arabic poetical tradition of having every feature of the beloved woman associated with a metaphor of its own.

According to Hamilton's reconstruction, the rectangular part of the bahw outside the apse was covered with a dome. Underneath the dome was a painted stucco frieze showing a row of partridges (see fig. 2). In Greek tradition the partridge was associated with sexuality, as Aristotle wrote in his Historia Animalium. ${ }^{29}$ It is quite likely that this same symbolism was attached to the partridge representations in the bahw. The multiple representation of this bird in the bahw would seem to provide additional support for the interpretation of the erotic iconography of the mosaic panel.

Another detail of this mosaic panel sheds further light on its meaning. The border of the panel imitates the tassels of a textile of the kind used for draperies, clothes, or curtains. $^{30}$ This feature, which has no parallel in any other known Umayyad mosaic, establishes a parallel between the panel and a type of textile cover. We know from various accounts of the ceremonial of the Umayyads, Abbasids, and Fatimids that the caliphs sat behind curtains from where they appeared at specified moments in the ritual. Walid is reported to have sat behind a curtain listening to music or poetry. Singers and musicians traditionally performed behind curtains. The bahw at Khirbat al-Mafjar most likely was closed off by curtains, perhaps embroidered or woven with patterns similar to those on the mosaics. The Sasanian kings sat in the wintertime beneath curtains representing garden landscapes to evoke nature's rebirth in spring. Similarly, in the Fatimid period, the curtains of palaces are described as having been adorned with representations of animals and trees.

The border of our mosaic panel, by creating an association with a curtain or drape, could well have been intended to suggest that the whole scene depicted has to be understood in the sense of intimacy. In Arabic the word satr and other words derived from the same stem ( $s-t-r)$ are used not only to designate the curtain or cover itself but, by extension in a figurative sense, to refer to intimacy. In the Arabic medieval literary tradition, closing a door or a curtain behind a couple is a metaphor for the sexual act. A hadith text stipulates that whenever a man withdraws with a woman behind a door or a curtain he is liable to pay the dowry. ${ }^{31}$ The literary critic Jurjani (d. 1078) sees in this motif a metaphor that expresses intimate relations and implies the payment of a dowry: man arkhā satran aw aghlaqa bāban wajaba almahra. ${ }^{32}$

The question that now arises is to what extent poetry or other literary texts can be used to interpret images in Islamic art. Here we have to note a difference between the Iranian and the Arab world. In the arts of Iran, where figural representations never ceased to play a prominent role in the arts, references to epics and poetical works are common. For the Arab world, where pictorial motifs are less frequent, this problem is more complicated. We are used to seeing epigraphy in Islamic religious architecture as a medium equivalent to imagery in other arts. However, the art of the Umayyad period was still under the impact of pre-Islamic traditions 


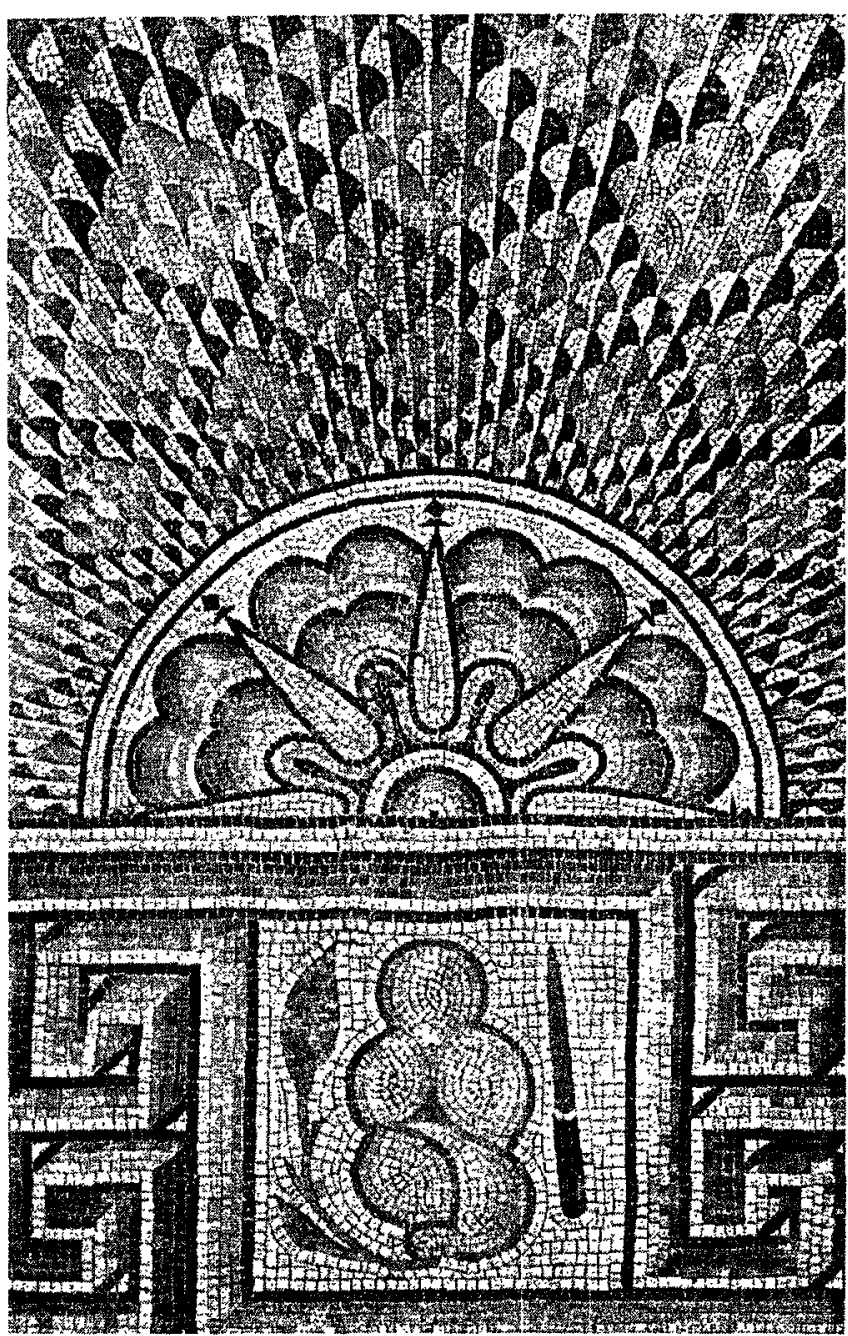

Fig. 5. The rebus of Walid. (after Hamilton)

and made use of images. If Klaus Brisch's interpretation of the mosaics of the Umayyad mosque at Damascus is correct, the patterns illustrated there are closely based on specific texts in the Qur'an that describe architecture in paradise. ${ }^{93}$ If we go back to pre-Islamic Christian traditions in this region we find that mosaics were used to depict literary texts as patterns for architectural decoration. At St. Mary's Church at Madaba, the so-called Hyppolitos Hall, attributed to the sixth century, is decorated with a mosaic pavement illustrating scenes from Euripides' play, Hyppolitos. ${ }^{34}$

Poetry was the major form of art among the preIslamic Arabs, and it was the major form of literature under the Umayyads. Walid was a poet who, unlike others, was a royal figure who had the means and power of propagating his poetical ideas through other media. The illustration of a poetical image in a mosaic panel would not be exceptional in the context of Khirbat alMafjar; it has a parallel in the representation which Hamilton identifies as a rebus, and which shows a fruit sprouting, perhaps the stylized figure of a woman, next to which is a knife, a masculine symbol (fig. 5). Hamilton recognized in this rebus the name Walid, which literally means sprout or newborn.

This and the lion's panel are the only ones in the mosaic carpet that contain representational images, and both of them seem to refer in an encoded manner to the person of Walid. They are somewhat provocative images of Walid as he liked to present himself.

University of Munich

Munich, Germany

\section{NOTES}

Author's note: I would like to thank Professor Wolfhart Heinrichs and Dr. James Montgomery for their generous advice in matters of Arabic poetry.

1. R.W. Hamilton, Khirbat al-Mafjar: An Arabian Mansion in the Jordan Valley (Oxford, 1959); idem, "Who Built Khirbat al-Mafjar?," Levant 1 (1969): 61-67; idem, "Khirbat al-Mafjar: The Bath Hall Reconsidered," Levant 10 (1978): 126-38; Oleg Grabar, "The Umayyad Palace at Khirbat al-Mafjar," Archaeology 8 (1955) : 228-35; Richard Ettinghausen, "The Throne and Banquet Hall of Khirbat al-Mafjar," From Byzantium to Sasanian Iran and the Islamic World (Leiden, 1972), pp. 2-69; Eva Baer, "Khirbat al-Mafjar," Encyclopaedia of Islam, 2nd ed., vol. 3.

2. R.W. Hamilton, Walid and His Friends: An Umayyad Tragedy, Oxford Studies in Islamic Art 6 (Oxford, 1988).

3. For Walid's life and poetry, see Dieter Derenk, Leben und Dichtung des Omaiyadenkalifen al Walid ibn Yazid: Ein quellenkritischer Beitrag (Freiburg, 1974); Robert Hillenbrand, "La Dolce Vita in Early Islamic Syria of Later Umayyad Palaces," Art History 5 (1987) : 1-35, with an extensive bibliography.

4. Francesco Gabrieli, Storia della tetterature araba (Milan, 1956), pp. $136 \mathrm{ff}$., "Al-Walid ibn Yazid: Il califfo e il poeta," Rivista degli Studi orientali 15 (1934): 1-64; Derenk, al-Walid, pp.57-62; alIșfahānì, Kitäb al-Aghänī, 21 vols. (Cairo, 1927-73), 7: 20.

5. Ettinghausen, "Throne and Banquet Hall" p.45; idem, Arabische Malerei (Geneva, 1962), pp.38ff.; Willy Hartner and Richard Ettinghausen, "The Conquering Lion: The Life Cycle of a Symbol," Oriens 17 (1964): 161-71; reprinted in Richard Ettinghausen, Islumic Archaeology, Collected Papers, ed. M. RosenAyalon (Berlin, 1984), pp. 693-711.

6. Kurt Weitzmann, "Probleme der mittelbyzantinischen Renaissance," Jahrbuch des Deutschen Archäologischen Instituts 48, Archäologischer Anzeiger, 1-2 (1933): 337-60, figs. 14-15.

7. Janine Balty, Mosaïques antiques de Syrie (Brussels, 1977), pp. 130f.; idem, "Die Antiken Mosaiken in Syrien und in Jorda- 
nien," Byzantinische Mosaiken aus Jordanien, ed. H. Buschhausen (Vienna, 1986), pp.127-56. In the latter article the author compares the Syrian and the Jordano-Arabian schools of mosaic pavements.

8. Cf. Oleg Grabar, "La place de Qusayr Amrah dans l'art profane du Haut Moyen Age," Cahiers archéologiques 36 (1988): $75-83$.

9. Now at the Baltimore Museum of Art (no.37.119).

10. M. Piccirillo, "Die Mosaiken von Justinian bis Jazid II," Byzantinische Mosaiken aus Jordanien (cited above, n.7), p.54, (fig. 41); pp. $72 f$.

11. Ettinghausen, "Throne and Banquet Hall," p. 46.

12. Hamilton, Walid and His Friends, p.168, appendix 3; p.195, no. 101 .

13. Ibid., p.122, appendix 3; p.188, no. 64 .

14. J.C. Bürgel, "The Lady Gazelle and Her Murderous Glances," Joumal of Arabic Literature 20 (1989): 1-11.

15. F. Viré, "Ghazāl," EI 2nd ed., vol. 2.

16. A.J. Wensinck and Ch. Pellat, "Hūr," EI 2nd ed., vol. 3.

17. Hamilton, Walid and His Friends, p.167, appendix 3, p.194, no. 98.

18. Bürgel, "Lady Gazelle," p.10, cites Damìī (1331-32) who must have copied a much earlier source; (attributed to) Ibn Sirin (d. 728), Tafsir al-ahläm, 2 vols. (Beirut, 1995), 1: 246.

19. In order to be more faithful to the Arabic text, I have modified Hamilton's version, Walid and His Friends, p. 168, appendix 3; p. 195, no. 101.

20. Bürgel, "Lady Gazelle," p.4.

21. Ibid., p. 2.

22. Cited by Bürgel, ibid.
23. Hussein Bayyud, Die Stadt in der arabischen Poesie bis 1258 n.Chr. (Berlin, 1988), p. 68.

24. H. Kindermann, "al-Asad," EI 2nd ed., vol. 1; Max Grünert, Der Löwe in der Literatur der Araber (Prague, 1899).

25. Balādhurī, text cited by Dieter Derenk, Leben und Dichtung, p. 68 (Arabic appendix).

26. G. Schoeller, Arabische Naturdichtung (Beirut, 1974), pp. $18 \mathrm{ff}$.

27. Hamilton translates junaynati as paradise; Walid and His Friends, p. 94, appendix 3, p.181, no. 32 .

28. Ibid., p. 148, appendix 3, p.191, no. 82 .

29. H. Buschhausen, "Die Marienkirche von Madaba und der Saal des Hippolytos," Byzantinische Mosaiken aus Jordanien, ed. $\mathrm{H}$. Buschhausen (Vienna, 1986), pp. 139-56, see esp. p.147.

30. Hillenbrand, "Dolce Vita," p.10, n. 82; H.G. Farmer, A Fistory of Arabian Music to the XIIIth Century (London, 1967); for the curtain in Fatimid ceremonial, see G. Wiet, Cairo, City of Art and Commerce (Oklahoma City, 1964), pp. 20, 22.

31. Ibn Manzūur, Lisān al ${ }^{c}$ Arab (Beirut, 1988), 7: 169.

32. Al-Jurjānī, al-muntakhab min kināyat al-udabā wa ishārat al bulagh $\vec{a}^{2}$ (Cairo, 1908), p.10; see also R. Dozy, Supplément aux Dictionnaires Arabes (Leiden, 1881), 1: 631 ff.

33. Oleg Grabar, "The Umayyad Dome of the Rock in Jerusalem," Ars Orientalis 3 (1959): 33-62; Klaus Brisch, "Observations on the Iconography of the Mosaics in the Great Mosque at Damascus," Content and Context of Visual Arts in the Isiamis. World, ed. P.P. Soucek (London, 1988), pp.13-20; Barbara Finster, "Die Mosaiken der Umayyadenmoschee von Damaskus," Kunst des Orients, 7 (1970-71): 83-140, esp. pp.118f.

34. Buschhausen, "Die Marienkirche" (cited above n.29). 